\title{
ОЦНКА ЕФЕКТИВНОСТІ ВПРОВАДЖЕННЯ ПРОГРАМИ ОПТИМІЗАЦІЇ РОЗВИТКУ ТА ПСИХОКОРЕКЦІЇ СОЦІАЛЬНИХ ОЧІКУВАНЬ ОСОБИСТОСТІ
}

УдК: $316.6 / .47: 159.923 .2$

\section{Попович Ігор Степанович}

Кандидат психологічних наук, доиент, доиент кафедри педагогіки, психології й освітнього менеджменту Херсонського державного університету, Херсон (Украӥна)

\begin{abstract}
Анотація. У статті обтрунтовано змістово-процесуальні особливості програми оптимізації розвитку та психокорекиії соціальних очікувань особистості. Визначено принципи, описано організацію і умови проведення формувального етапу дослідження. Подано програму тренінгових занять та післятренінгового супроводження «Очікуваний результат». Розкрито сутність напрямків формувально-корекційного етапу програми дослідження: формувальнорозвивального, профілактики та психокорекиії. Окреслено доцільність $і$ змістові особливості післятренінгового супроводження.

Проведено контрольний етап експериментального дослідження. Розглянуто головні результати впровадження програми дослідження сочіальних очікувань особистості. Оцінено ефективність впровадження програми оптимізації розвитку та психокорекції соціальних очікувань особистості. Здійснено обтрунтування отриманих експериментальних результатів дослідження.
\end{abstract}

Ключові слова: соціальні очікування, оптимізація розвитку соціальних очікувань, психокорекція сочіальних очікувань, програма дослідження.

Постановка наукової проблеми та її значення. Соціально-психологічне забезпечення оптимізації розвитку та психокорекції соціальних очікувань особистості передбачало створення, і реалізацію програми формувального експерименту. Мета програми полягала у забезпеченні сприятливих психологопедагогічних умов формування, розвитку, оптимізації і психокорекції досліджуваних експериментальних груп 3 урахуванням особли- востей їхньої діяльності та функціонального призначення, в залежності від соціокультурного простору, укладу, сфери діяльності. Теоретико-методологічний аналіз проблеми засвідчив, що психологія соціальних очікувань особистості базується на дослідженні соціальних очікувань як психічного процесу, стану і властивості, які утворюють основний понятійний зміст досліджуваного феномену [1-2]. Соціальні очікування мають глибоку психологіч- 
ISSN 2414-004X (Online)

ну сутність, що потребує досконалого дослідження. Вони носять поліфункційний характер, здатні виступати механізмами низки соціально-психологічних явищ, процесів. На соціальні очікування впливає величезна гамма складних чинників за своєю суттю та функціонуванням, і чинників нижчого, вторинного порядку, які є не менш важливими. Значущим $є$ погляд на соціальні очікування особистості як процес конструювання і відображення соціальної дійсності, який реалізується механізмами інтеріоризації та екстеріоризації, інтерналізації, екстерналізації, об’єктивації, рефлексії, ідентифікації та стереотипії. Теоретично обгрунтовано, що варіативність реакцій на конкретний перебіг подій чи участь в міжособистісній взаємодії сприяє утворенню і розвитку складної розгалуженої системи соціальних очікувань особистості, яка вибудовується в ієрархічному порядку, утворюючи так зване «дерево соціальних очікувань особистості». Теоретико-методологічні положення дозволили окреслити контури програми дослідження, врахувати змістові та процесуальні особливості досліджуваного феномену. Психологічні механізми і функції дозволяють операціоналізувати програму дослідження, зробити іiі дієвим засобом оптимізації розвитку та психокорекції соціальних очікувань досліджуваних.

Аналіз останніх досліджень. Розкриття змістово-процесуальних особливостей програми оптимізації розвитку та психокорекції соціальних очікувань особистості, умови впровадження, оцінка ефективності формува- льних впливів продовжує наші наукові пошуки, i є черговим логічним кроком у дослідження психології соціальних очікувань особистосTi.

Мета статті полягає у розкритті сутності, оцінці ефективності впровадження програми оптимізації розвитку та психокорекції соціальних очікувань особистості.

\section{Виклад основного матеріалу й обгру-} нтування отриманих результатів дослідження. Окреслимо особливості ситуації, які пов'язані з впровадженням програми для співробітників ТЦ «33м²етра» ТОВ «Максі Трейд» (м. Білгород-Дністровський). Реалізацію програми оптимізації розвитку та психокорекції вимагала природно створена конфліктна ситуація, пов'язана з річною недостачею, пересортуванням і виявленням значної кількості некондиційного товару. 32009 по 2016 рік автором реалізовано проект «HR-структура ТОВ «МАК «Монополія»»». У рамках цього проекту автором, бізнес-тренерами відділу навчання і розвитку персоналу HR-структури апробовано низку тренінгових програм, у яких здійснювалася оптимізація розвитку та психокорекція соціальних очікувань. У різний час учасниками тренінгових програм був персонал торгових центрів, комерційних та адміністративних відділів організацій TOB «МАК «Монополія» (м. Херсон), TOB «Максі Трейд» (м. БілгородДністровський), ТОВ «НовостройЛюкс» (м. Нікополь), ТОВ «Максі Крим» (м. Джанкой) та ін., Досвід організова- 
ної та проведеної нами роботи дозволив створити оптимальний варіант програми тренінгових занять та післятренінгового супроводження «Очікуваний результат», врахувати вимоги виробничої ситуації, особливості соціокультурного простору середовища міжособистісної взаємодії.

\section{Розкриємо сутність програми} «Очікуваний результат», апробованої в торгових центрах Всеукраїнської мережі будівельно -господарських супермаркетів «33м² етра», адаптованої до умов соціокультурного простору комерційної приватної організації і впровадженої у виробничий процес «33м²етра» TOB «Максі Трейд» (м. БілгородДністровський). Програма представляла поєднання тренінгових занять і післятренінгового супроводження, загальним обсягом 40 годин, 3 частковим відривом від виробництва. Програму рекомендовано впроваджувати безперервно, впродовж робочого тижня. Кожного тренінгового дня рекомендовано проводити 4 години класичного тренінгового заняття i 4 години післятренінгового супроводження, тобто закріплення засвоєного матеріалу на робочих місцях, де розв'язуються адміністративні та виробничі завдання. Заздалегідь готується графік реалізації програми з планом занять і об'єднанням персоналу у тренінгові групи. Програму тренінгових занять та післятренінгового супроводження «Очікуваний результат» рекомендовано проводити в торгових центрах з широким асортиментом товару кла- com non-food, системою самообслуговування DIY (do it yourself). Для впровадження в інших типах об'єктів торгівлі необхідно здійснити адаптацію програми до завдань навчальнопрофесійної підготовки і особливостей соціокультурного простору. Найефективнішим $є$ впровадження на етапі запуску чи ребрендингу торгового центру. Представимо програму тренінгових занять та післятренінгового супроводження «Очікуваний результат» табл. 1.

Метою тренінгового циклу занять було формування уявлень про ефективну реалізацію бізнес-процесу та спроба його реалізувати, тренування необхідних навиків ефективної комунікації, організації роботи $з$ продажу товарів. Метою післятренінгового супроводження було закріплення на практиці вищеперелічених вмінь та навичок. Комбінована модель навчально-професійної підготовки дозволила швидко та ефективно, з мінімальними витратами часу і матеріальних засобів отримати «результат на вкладений ресурс».

Впровадження програми організовано наступним чином. У першій частині робочого дня, 38.00 до 12.00, проводилися тренінгові заняття 3 відривом від виробництва, далі 3 12.00 до 13.00 - обідня перерва, і з 13.00 до 17.00 - післятренінгове супроводження, без відриву від виробництва. Заздалегідь підготовлено графік реалізації програми з планом занять і об'єднано штатний персонал у тренінгові групи. На цьому етапі враховано графік ро- 
Таблиия 1

\section{Програма тренінгових занять та післятренінгового супроводження}

\section{«Очікуваний результат»}

\begin{tabular}{|c|c|c|c|}
\hline $\begin{array}{c}\text { № } \\
\text { 3/ח } \\
\end{array}$ & Тематика занять & $\begin{array}{c}\text { Учасники заходу (кількість штатних оди- } \\
\text { ниць, загальна кількість) } \\
\end{array}$ & $\begin{array}{l}\text { Обсяг у } \\
\text { годинах }\end{array}$ \\
\hline 1 & 2 & 3 & 4 \\
\hline 1. & $\begin{array}{c}\text { «Моделі і стратегії ефективної комунікації } \\
\text { в системі управління» (для адміністратив- } \\
\text { ного персоналу) }\end{array}$ & $\begin{array}{c}\text { Директор ТЦ (1), начальник охорони (1), } \\
\text { менеджер по персоналу (1), категорійні } \\
\text { менеджери (6), ст. бухгалтер (1), ст. касир } \\
\text { (1). Всього } 11 \text { учасників. }\end{array}$ & 4 \\
\hline 2. & $\begin{array}{c}\text { Післятренінгове супроводження учасників } \\
\text { заняття «Моделі і стратегії ефективної ко- } \\
\text { мунікації в системі управління» (для адмі- } \\
\text { ністративного персоналу) }\end{array}$ & $\begin{array}{c}\text { Директор ТЦ (1), начальник охорони (1), } \\
\text { менеджер по персоналу (1), категорійні } \\
\text { менеджери (6), ст. бухгалтер (1), ст. касир } \\
\text { (1). Всього } 11 \text { учасників. }\end{array}$ & 4 \\
\hline 3. & $\begin{array}{c}\text { «Моделі і стратегії ефективної комунікації } \\
\text { в системі обліку і продаж» (для продавців- } \\
\text { консультантів і бухгалтерського персона- } \\
\text { лу) }\end{array}$ & $\begin{array}{c}\text { Продавець-консультант (7), касир- } \\
\text { оператор (2), бухгалтер внутрішнього об- } \\
\text { ліку (1), бухгалтер-інвентаризатор (1). } \\
\text { Всього } 11 \text { учасників. }\end{array}$ & 4 \\
\hline 4. & $\begin{array}{c}\text { Післятренінгове супроводження учасників } \\
\text { заняття «Моделі і стратегії ефективної ко- } \\
\text { мунікації в системі обліку і продаж» (для } \\
\text { продавців-консультантів і бухгалтерського } \\
\text { персоналу) }\end{array}$ & $\begin{array}{c}\text { Продавець-консультант (7), касир- } \\
\text { оператор (2), бухгалтер внутрішнього об- } \\
\text { ліку (1), бухгалтер-інвентаризатор (1). } \\
\text { Всього } 11 \text { учасників. }\end{array}$ & 4 \\
\hline 5. & $\begin{array}{c}\text { «Моделі і стратегії ефективної комунікації } \\
\text { в системі обліку і продаж» (для продавців- } \\
\text { консультантів і бухгалтерського персона- } \\
\text { лу) }\end{array}$ & $\begin{array}{c}\text { Продавець-консультант (7), касир- } \\
\text { оператор (2), бухгалтер внутрішнього об- } \\
\text { ліку (1), бухгалтер-інвентаризатор (1). } \\
\text { Всього } 11 \text { учасників. }\end{array}$ & 4 \\
\hline 6. & $\begin{array}{c}\text { Післятренінгове супроводження учасників } \\
\text { заняття «Моделі і стратегії ефективної ко- } \\
\text { мунікації в системі обліку і продаж» (для } \\
\text { продавців-консультантів і бухгалтерського } \\
\text { персоналу) }\end{array}$ & $\begin{array}{c}\text { Продавець-консультант (7), касир- } \\
\text { оператор (2), бухгалтер внутрішнього об- } \\
\text { ліку (1), бухгалтер-інвентаризатор (1). } \\
\text { Всього } 11 \text { учасників. }\end{array}$ & 4 \\
\hline 7. & $\begin{array}{c}\text { «Введення в посаду продавця- } \\
\text { консультанта» (для щойно прийнятих про- } \\
\text { давців-консультантів) }\end{array}$ & Стажер продавець-консультант (8) & 4 \\
\hline 8. & $\begin{array}{c}\text { Післятренінгове супроводження учасників } \\
\text { заняття «Введення в посаду продавця- } \\
\text { консультанта» (для щойно прийнятих про- } \\
\text { давців-консультантів) }\end{array}$ & Стажер продавець-консультант (8) & 4 \\
\hline 9. & $\begin{array}{c}\text { «Методи і прийоми ефективних продаж. } \\
\text { Очікуваний результат. Виконання пла- } \\
\text { ну» (для торгового персоналу, що пройшов } \\
\text { випробувальний термін) }\end{array}$ & $\begin{array}{c}\text { Категорійний менеджер (3), продавець- } \\
\text { консультант (7). Загальна кількість не пе- } \\
\text { ревищує } 12 \text { учасників. }\end{array}$ & 4 \\
\hline 10. & $\begin{array}{c}\text { Післятренінгове супроводження учасників } \\
\text { заняття «Методи і прийоми ефективних } \\
\text { продаж. Очікуваний результат. Виконання } \\
\text { плану» (для торгового персоналу, що прой- } \\
\text { шов випробувальний термін) }\end{array}$ & $\begin{array}{c}\text { Категорійний менеджер (6), продавець- } \\
\text { консультант (28). Задіяний весь торговий } \\
\text { персонал }\end{array}$ & 4 \\
\hline \multicolumn{2}{|r|}{ Всього: } & \multicolumn{2}{|l|}{40 годин } \\
\hline
\end{tabular}


торговий персонал на тренінгове заняття, оскільки на робочих місцях відбувається прийом товару, викладка, торгівля, оформлення документів, упакування і відвантаження, та й неефективно одночасно тренувати 28 продавців-консультантів. Так само неможливо задіяти весь штат торгового персоналу у післятренінговому супроводженні, оскільки згідно графіка $є$ персонал на вихідному дні.

Унікальність проблемної ситуації вносила вагомі корективи у зміст та мету програми «Очікуваний результат». Суть ï полягала у тому, що за результатами проведення річної інвентаризації у ТЦ «33м² етра» (м. БілгородДністровський) зафіксовано недостачу товароматеріальних цінностей на 38 124,31 грн., персортування на 12 895,13 грн. і некондиційний товар на суму 5 654,12 грн., грубі порушення трудової дисципліни, касової дисципліни, відсутність або спотворене виконання бізнес-процесів, і небажання дотримуватися регламентів роботи. Адміністрацією компанії прийнято рішення компенсувати збитки організації за рахунок накладення зарплатних штрафних санкцій на матеріальновідповідальних учасників процесу - продавців-консультантів, згідно актів про результати інвентаризація за звітній період. Це привело до ескалації конфлікту, дестабілізації міжособистісної взаємодії, плинності персоналу. На час проведення констатувального етапу експерименту, неукомплектованість сягала 10 продавців-консультантів, 2 категорійні ме- неджери, 1 касир-оператор, 1 бухгалтер і 2 охоронці, загальною кількістю 15 штатних одиниць. За штатним розкладом у торговому центрі - 51 штатна одиниця, укомплектованість стрімко впала до 70,59\%. На час проведення формувального експерименту було вирішено питання річної недостачі, укомплектовано персонал на 94,12\% згідно штатного розкладу, прийнято низку заходів з подолання плинності персоналу. Метою формувальних впливів було завдання у короткий проміжок часу вивести персонал торгового центру на достатній рівень функціональної готовності реалізовувати завдання і плани організації, що знайшло своє відображення у програмі тренінгових занять та післятренінгового супроводження «Очікуваний результат». Подамо короткий зміст програми. Розкриємо сутність $\mathrm{i}$ деякі змістово-процесуальні особливості тренінгових занять.

Тренінгове заняття «Моделі і стратегії ефективної комунікації в системі управління» було вступним, для адміністративного персоналу. На вступному занятті найважливішим завданням, яке ми розв'язували, було становлення групових норм і засвоєння учасниками головних вимог тренінгу. Докладно ознайомлено всіх учасників 3 головними нормами i принципами спілкування у тренінговій групі. У програмі оптимізації розвитку та психокорекції соціальних очікувань знайшли відображення наступні принципи: спілкування «тут і тепер», персоніфікації висловлювань, наголо- 
шування мови почуттів, активності, довірливого спілкування, конфіденційності.

Для оптимізації рівня очікувань співробітників торгового центру важливо знати ті уявлення та очікування, які склалися в міжособистісних контактах, стосунках, взаєминах 3 іншими співробітниками стосовно виконання ним посадових обовязків, їхньої соціальної ролі. Нами здійснено класифікацію членів міжособистісної взаємодії за рівнями сформованості та типами соціальних очікувань. Це стало необхідною умовою вибору правильної стратегії спілкування 3 будь-якою групою. Оскільки нерідко в умовах залежності однієї людини від іншої дійсні ставлення не проявляються, а приховуються, маскуються. Пізнати очікування учасників міжособистісної взаємодії - важливе завдання, успішне розв'язання якого вимагає наявності спеціальних психологічних знань.

Учасниками першого тренінгового заняття «Моделі і стратегії ефективної комунікації в системі управління» $є$ адміністративний персонал, який здійснює керівництво торговим центром, відповідає за ключові керівні ланки роботи. Ми почали реалізацію програми i виконання формувальних впливів 3 «голови», що допомогло краще збагнути сутність проблеми і озброїтися необхідними засобами у роботі з іншими тренінговими групами торгового центру.

На початковому занятті тренінгової групи нами традиційно використовувалася авторська методика «Очікувана ситуація». Природність створеної ситуації дозволяла отримати валідні емпіричні значення досліджуваних показників властивостей соціальних очікувань. Методика «Очікувана ситуація» дозволяла зафіксувати окреслений соціальнопсихологічний контекст досліджуваної групи. Учасники заняття описували свої очікування, сподівання, надії щодо тренінгу. Зміст своєї очікуваної соціальної дійсності досліджувані фіксували на окремих аркушах.

Тренінгові заняття зазвичай починалися $з$ тренінгових вправ, що слугували розминкою, зокрема «Хто ця людина?». Дана методика дозволяла відпрацювати техніку відкритих запитань. Досвід, якого набували співробітники у рамках реалізації програми, додавав їм впевненості, створював своєрідний соціальнопсихологічний «імунітет», котрий допомагав розв'язувати складні завдання у міжособистісних взаєминах, збагачувати їх, долати труднощі.

Складнішим завданням тренінгової роботи була «Побудова ефективного бізнеспроцесу обліку товароматеріальних цінностей (ТМЦ)». Задавалися конкретні умови виконання даного завдання. Зокрема, побудова блок-схем, розмежування зон відповідальності, визначення очікувань і поведінки учасників процесу. Це дозволяло неодноразово здійснювати акти планування, прогнозування, передбачення ймовірного розвитку подій, моделювати ситуації, аналізувати і враховувати ризи- 
ки. Адміністративний персонал наводив приклади і давав пояснення, чому мала місце недостача і що потрібно робити, щоб уникнути небажаного результату, вчився вибудовувати алгоритм досягнення бажаного очікуваного результату.

Учасники тренінгового заняття «Моделі і стратегії ефективної комунікації в системі обліку і продаж» проходили тренування за схожим сценарієм, але ситуації, які нами розглядалися, стосувалися сфери бухгалтерського обліку, касової дисципліни, взаємин 3 покупцями і супроводжувалися прагненням зрозуміти їх очікування. Зазначимо, що виробнича необхідність зумовила об'єднати персонал у дві схожі групи, які складалися 3 продавців-консультантів, касирівоператорів, бухгалтерів внутрішнього обліку і бухгалтерів-інвентаризаторів.

Оскільки на час проведення формувального експерименту було прийнято на роботу вісім продавців-консультантів, категорійного менеджера, касира-оператора і охоронця, кількістю 12 штатних одиниць, необхідно було здійснювати стажування і адаптацію персоналу до нових умов роботи, оптимізувати очікування учасників процесу. У цьому контексті проведення тренінгового заняття «Введення в посаду продавця-консультанта» для торгового персоналу набувало неабиякої актуальності. Щось схоже для інших оптантів проводити було недоцільно. Формувальні впливи на цих учасників були реалізовані че- рез післятренінгове супроводження. Тренінг «Введення в посаду продавця-консультанта» $\epsilon$ звичайним тренінговим заняттям, яке наближає стажерів до сприятливого очікуваного результату.

Тренінгове заняття «Методи і прийоми ефективних продаж. Очікуваний результат. Виконання плану» є схожим за своєю метою $з$ попереднім заняттям, що проведено для стажерів, але відрізняється рівнем і змістово-процесуальними особливостями. Проведено тренінгову вправу «Очікуваний результат». Окреслено суть завчасно підготовленої експериментальної ситуації. Учасники вчилися ставити себе на місце покупця, свого керівника, що дозволяло цілісно зрозуміти деякі бізнес-процеси, активізувати рефлексивні ресурси учасників тренінгу, сприяло конструктивній побудові і реалізації моделі очікуваного майбутнього.

Післятренінгове супроводження, метою якого було закріпити отримані вміння i навички, дало можливість визначити реальну соціальну дійсність, мотиви участі в тренінгу, відповідно конкретизувати соціальні очікування і прагнення співробітників торгового центру. Через супроводження ми здійснювали активізацію ресурсів учасників, формували цікавість до нового, налаштовували на тривалу дистанцію. Нами успішно закріплено створений на початковому етапі співпраці позитивний образ програми «Очікуваний результат». Для ефективного післятренінгового 
супроводження застосовано низку психотерапевтичних та психотехнічних прийомів, серед яких: налагодження психологічного контакту, створення сприятливого емоційного фону. Впродовж індивідуальної форми супроводження суттєві вербальні та невербальні реакції занотовано у протокол, що дозволило отримати і зафіксувати значну кількість відповідей, описати психологічні стани очікуваної поведінки, які допомогли краще збагнути змістово-процесуальні особливості соціальних очікувань учасників програми оптимізації розвитку та психокорекції соціальних очікувань, доторкнутися і відстежити чутливу грань досліджуваного феномену.

Завершальною ланкою реалізації програми «Очікуваний результат» було проведення авторської методики «Реалізація очікувань». Застосування методики «Реалізація очікувань» дозволило отримати емпіричні дані дослідження соціальної дійсності 3 позиції кожного учасника взаємодії, окреслити рівні та виміри властивостей соціальних очікувань досліджуваних.

Контрольним етапом дослідження охоплено співробітників трьох торгових центрів мережі будівельно-господарських супермаркетів «33м²етра». Експериментальну вибірку склали співробітники Трейд» (м. Білгород-Дністровський, Одеської обл.), загальною кількістю $\mathrm{n}=45$. Контрольну вибірку склали співробітники TOB «Новострой-Люкс» (м. Нікополь, Дніп- ропетровської обл.), загальною кількістю $\mathrm{n}=45$. Третю вибірку, яку утворили співробітники ТОВ «Максі Крим» (м. Джанкой), ми не розглядали як контрольну, оскільки особливий статус (тимчасово окупована РФ територія Крим) та й контекст, що з цим зв'язаний, вносили свої особливості, що не дозволило даний торговий цент розглядати як контрольну вибірку.

Порівняння контрольної та експериментальної груп до початку впровадження програми тренінгових занять, післятренінгового супроводження «Очікуваний результат» показує значущі розбіжності за показниками дослідження, оскільки констатувальний етап дослідження проведено після річної інвентаризації у ТЦ «33м²етра» (м. Білгород-Дністровський). Актами річної інвентаризації зафіксовано недостачу товароматеріальних цінностей, персортування, некондиційний товар на значну суму. Також виявлено грубі порушення трудової та касової дисципліни, та ін. порушення. Така соціальна дійсність вимагала суттєвих позитивних змін. Значущою є перевага показника обізнаності про передбачуваний перебіг подій контрольної групи над експериментальною: низького рівня $(\mathrm{n}=5 ; 11,36 \%)$ і середнього рівня $(\mathrm{n}=35 ; 79,55 \%)$. Інші показники соціальних очікувань експериментальної групи показують відносно рівномірний розподіл: високого рівня 20,00\%, середнього - орієнтовно 60,00$65,00 \%$ і решта - показники низького рівня. Показники соціальних очікувань контрольної 
групи мають значно вищі значення, зокрема, рівень соціальних очікувань складає: високий (n=19; 43,18\%), середній (n=24; 54,55\%), низький $(\mathrm{n}=1 ; 2,27 \%)$. Показники рівнів соціальних очікувань всіх учасників дослідження мають ширшу варіативність діапазону значень, на відміну від попередньої пари експериментальної і контрольної груп $\left(\mathrm{PCO}_{\mathrm{o}}=41-89\right)$.
Перейдемо до розгляду головних результатів впровадження програми. Проаналізуємо експериментальні дані, що характеризують соціальні очікування як процес і результат психічної регуляції поведінки. Подамо зміни досліджуваних показників соціальних очікувань в експериментальній групі (див. табл. 2).

Таблиия 2

Порівняння результатів показників соціальних очікувань експериментальної групи до та після формувального експерименту

\begin{tabular}{|c|c|c|c|c|c|c|c|c|}
\hline \multirow[t]{2}{*}{$\begin{array}{c}\text { № } \\
\text { 3/ } \\
\Pi\end{array}$} & \multirow[t]{2}{*}{$\begin{array}{c}\text { Показник соці- } \\
\text { альних очіку- } \\
\text { вань }\end{array}$} & \multirow{2}{*}{$\begin{array}{l}\text { Рівень } \\
\text { соціаль- } \\
\text { них очі- } \\
\text { кувань }\end{array}$} & \multicolumn{2}{|c|}{$\begin{array}{c}\text { До експери- } \\
\text { менту (35 } \\
\text { співробітни- } \\
\text { ків) }\end{array}$} & \multicolumn{2}{|c|}{$\begin{array}{c}\text { Після експе- } \\
\text { рименту (45 } \\
\text { співробітни- } \\
\text { ків) } \\
\end{array}$} & \multirow{2}{*}{$\begin{array}{c}\text { Т-критерій } \\
\text { Ф.Вілкоксон } \\
\text { a } \\
\text { (сума ран- } \\
\text { гів), } \mathrm{T}_{\mathrm{n}},{ }^{*} \\
\mathrm{~T}_{\mathrm{H}}^{* *} \\
\end{array}$} & \multirow{2}{*}{$\begin{array}{c}\text { Коеф. } \\
\text { значущо- } \\
\text { сті, } \\
\text { p } \leq 0,05\end{array}$} \\
\hline & & & К-сть & $\%$ & К-сть & $\%$ & & \\
\hline 1 & 2 & 3 & 4 & 5 & 6 & 7 & 8 & 9 \\
\hline \multirow{3}{*}{1.} & \multirow{3}{*}{$\begin{array}{c}\text { Рівень обізна- } \\
\text { ності про пе- } \\
\text { редбачуваний } \\
\text { перебіг подій, } \\
\text { ОП }_{\text {о }}\end{array}$} & високий & 5 & 14,29 & 5 & 11,11 & \multirow{3}{*}{$\begin{array}{c}\text { позитивні } \\
220,50 \\
\text { негативні } \\
30,50\end{array}$} & \multirow{3}{*}{0,001} \\
\hline & & середній & 20 & 57,14 & 32 & 71,11 & & \\
\hline & & низький & 10 & 28,57 & 8 & 17,78 & & \\
\hline \multirow{3}{*}{2.} & \multirow{3}{*}{$\begin{array}{c}\text { Рівень очікува- } \\
\text { ного ставлення } \\
\text { до учасників } \\
\text { міжособистіс- } \\
\text { ної взаємодії, } \\
\text { ОС }_{\text {о }} \\
\end{array}$} & високий & 7 & 20,00 & 13 & 28,89 & \multirow{3}{*}{$\begin{array}{c}\text { позитивні } \\
660,00 \\
\text { негативні } \\
35,00\end{array}$} & \multirow{3}{*}{0,381} \\
\hline & & середній & 22 & 62,86 & 28 & 62,22 & & \\
\hline & & низький & 6 & 17,14 & 4 & 8,89 & & \\
\hline \multirow{3}{*}{3.} & \multirow{3}{*}{$\begin{array}{c}\text { Рівень очікува- } \\
\text { них результа- } \\
\text { тів діяльності, } \\
\text { ОР }_{\text {о }} \\
\end{array}$} & високий & 7 & 20,00 & 11 & 24,44 & \multirow{3}{*}{$\begin{array}{c}\text { позитивні } \\
135,00 \\
\text { негативні } \\
10,00 \\
\end{array}$} & \multirow{3}{*}{0,015} \\
\hline & & середній & 21 & 60,00 & 31 & 68,89 & & \\
\hline & & низький & 7 & 20,00 & 3 & 6,67 & & \\
\hline \multirow{3}{*}{4.} & \multirow{3}{*}{$\begin{array}{c}\text { Рівень соціаль- } \\
\text { них очікувань, } \\
\text { РСО }\end{array}$} & високий & 7 & 20,00 & 17 & 37,78 & \multirow{3}{*}{$\begin{array}{c}\text { позитивні } \\
275,50 \\
\text { негативні } \\
9,50\end{array}$} & \multirow{3}{*}{0,007} \\
\hline & & середній & 23 & 65,71 & 24 & 53,33 & & \\
\hline & & низький & 5 & 14,29 & 4 & 8,89 & & \\
\hline
\end{tabular}

$\mathrm{T}_{\text {п }}$ * - сума позитивних рангів Т-критерія Ф. Вілкоксона.

$\mathrm{T}_{\text {н }}^{* *}$ - сума негативних рангів Т-критерія Ф. Вілкоксона. 
Порівняння результатів показників соціальних очікувань експериментальної групи до та після формувального експерименту підтвердило ефективність програми тренінгових занять та після тренінгового супроводження «Очікуваний результат». Констатуємо значущі позитивні зміни показника обізнаності про передбачуваний перебіг подій $\quad\left(\mathrm{T}_{\pi}=220,50\right.$; $\mathrm{p}=0,001)$, значущі позитивні зміни очікуваних результатів діяльності $\left(\mathrm{T}_{\Pi}=135,00 ; \mathrm{p}=0,015\right) \mathrm{i}$ значущі позитивні зміни показника рівня соці- альних очікувань досліджуваних $\left(\mathrm{T}_{\text {п }}=275,50\right.$; $\mathrm{p}=0,007)$. Незначущими $є$ позитивні зміни показника очікуваного ставлення до учасників міжособистісної взаємодії $\left(\mathrm{T}_{\Pi}=660,00\right.$; $\mathrm{p}=0,381)$. Констатуємо, що реалізована програма забезпечила зміни у складовій соціально-психологічних особливостей обізнаності особистості про передбачуваний перебіг подій та складовій соціально-психологічних особливостей регуляції особистістю очікуваних результатів діяльності, що і забезпечило значущі

Таблиия 3

Порівняння результатів показників соціальних очікувань контрольної групи до та після формувального експерименту

\begin{tabular}{|c|c|c|c|c|c|c|c|c|}
\hline \multirow[t]{2}{*}{$\begin{array}{l}\text { № } \\
\text { 3/ח }\end{array}$} & \multirow[t]{2}{*}{$\begin{array}{l}\text { Показник соціа- } \\
\text { льних очікувань }\end{array}$} & \multirow[t]{2}{*}{$\begin{array}{c}\text { Рівень со- } \\
\text { ціальних } \\
\text { очікувань }\end{array}$} & \multicolumn{2}{|c|}{$\begin{array}{c}\text { До експеримен- } \\
\text { ту (44 } \\
\text { співробітники) }\end{array}$} & \multicolumn{2}{|c|}{$\begin{array}{c}\text { Після експери- } \\
\text { менту (45 } \\
\text { співробітни- } \\
\text { ків) } \\
\end{array}$} & \multirow{2}{*}{$\begin{array}{c}\text { Т-критерій } \\
\text { Ф.Вілкоксон } \\
\text { a } \\
\text { (сума рангів), } \\
\mathrm{T}_{\text {п }} * \mathrm{~T}_{\mathrm{H}}^{* *}\end{array}$} & \multirow[t]{2}{*}{$\begin{array}{l}\text { Коеф. зна- } \\
\text { чущості, } \\
\text { p } \leq 0,05\end{array}$} \\
\hline & & & к-сть & $\%$ & к-сть & $\%$ & & \\
\hline 1 & 2 & 3 & 4 & 5 & 6 & 7 & 8 & 9 \\
\hline \multirow{3}{*}{1.} & \multirow{3}{*}{$\begin{array}{c}\text { Рівень обізнано- } \\
\text { сті про передба- } \\
\text { чуваний перебіг } \\
\text { подій, ОП }\end{array}$} & високий & 4 & 9,09 & 4 & 8,89 & \multirow{3}{*}{$\begin{array}{c}\text { позитивні } \\
10,50 \\
\text { негативні } \\
20,50\end{array}$} & \multirow{3}{*}{0,655} \\
\hline & & середній & 35 & 79,55 & 34 & 75,55 & & \\
\hline & & низький & 5 & 11,36 & 7 & 15,56 & & \\
\hline \multirow{3}{*}{2.} & \multirow{3}{*}{$\begin{array}{c}\text { Рівень очікува- } \\
\text { ного ставлення } \\
\text { до учасників } \\
\text { міжособистісної } \\
\text { взаємодії, ОС о }\end{array}$} & Високий & 14 & 31,82 & 13 & 28,89 & \multirow{3}{*}{$\begin{array}{c}\text { позитивні } \\
10,00 \\
\text { негативні } \\
0,00\end{array}$} & \multirow{3}{*}{0,059} \\
\hline & & середній & 29 & 65,91 & 31 & 68,89 & & \\
\hline & & низький & 1 & 2,27 & 1 & 2,22 & & \\
\hline \multirow{3}{*}{3.} & \multirow{3}{*}{$\begin{array}{l}\text { Рівень очікува- } \\
\text { них результатів } \\
\text { діяльності, ОР о }\end{array}$} & високий & 13 & 29,55 & 12 & 26,67 & \multirow{3}{*}{$\begin{array}{c}\text { позитивні } \\
15,00 \\
\text { негативні } \\
0,00\end{array}$} & \multirow{3}{*}{0,025} \\
\hline & & середній & 30 & 68,18 & 31 & 68,89 & & \\
\hline & & низький & 1 & 2,27 & 2 & 4,44 & & \\
\hline \multirow{3}{*}{4.} & \multirow{3}{*}{$\begin{array}{c}\text { Рівень соціаль- } \\
\text { них очікувань, } \\
\text { РCO }_{\text {o }}\end{array}$} & високий & 19 & 43,18 & 18 & 40,00 & \multirow{3}{*}{$\begin{array}{c}\text { позитивні } \\
25,50 \\
\text { негативні } \\
12,50\end{array}$} & \multirow{3}{*}{0,546} \\
\hline & & середній & 24 & 54,55 & 25 & 55,56 & & \\
\hline & & низький & 1 & 2,27 & 2 & 4,44 & & \\
\hline
\end{tabular}

$\mathrm{T}_{\text {п, }}$ * - сума позитивних рангів Т-критерія Ф. Вілкоксона.

$\mathrm{T}_{\text {н }}{ }^{*}$ - сума негативних рангів Т-критерія Ф. Вілкоксона. 
зміни показника рівня соціальних очікувань досліджуваного. Розглянемо результати змін у показниках соціальних очікувань досліджуваних контрольної групи (див. табл. 3).

Порівняння результатів показників соціальних очікувань контрольної групи, у якій не проводилися формувальні впливи, але до рівня якої нам необхідно «підтягнути» експериментальну групу, також засвідчило позитивні зміни. Тільки значущими є зміни показника очікуваних результатів діяльності $\left(\mathrm{T}_{\mathrm{n}}=69,50 ; \mathrm{p}=0,016\right)$. Зміни в інших показниках хоч і є позитивними, але не є значущі. Конста- туємо, що в контрольній групі зміни показника обізнаності про передбачуваний перебіг подій $\left(\mathrm{T}_{\Pi}=10,50 ; \mathrm{p}=0,655\right)$ є найменшими. Допускаємо, що чітка регламентація роботи, орієнтація на результат особливим чином позначаються на змістово-процесуальних особливостях обізнаності особистості про передбачуваний перебіг подій. Значущі зміни показника очікуваних результатів діяльності є підтвердженням нашого припущення. Розглянемо результати показників соціальних очікувань експериментальної та контрольної груп після формувального експерименту (див. табл. 4).

Таблиия 4

Порівняння результатів показників соціальних очікувань експериментальної та контрольної груп після формувального експерименту

\begin{tabular}{|c|c|c|c|c|c|c|c|c|}
\hline \multirow{2}{*}{$\begin{array}{l}\text { № } \\
\text { 3/ח }\end{array}$} & \multirow{2}{*}{$\begin{array}{l}\text { Показник соціа- } \\
\text { льних очікувань }\end{array}$} & \multirow{2}{*}{$\begin{array}{l}\text { Рівень со- } \\
\text { ціальних } \\
\text { очікувань }\end{array}$} & \multicolumn{2}{|c|}{$\begin{array}{c}\text { ЕГ* }(45 \\
\text { співробітників) }\end{array}$} & \multicolumn{2}{|c|}{$\begin{array}{c}\text { КГ** (45 } \\
\text { співробітників) }\end{array}$} & \multirow{2}{*}{$\begin{array}{l}\text { U-критерій } \\
\text { Манна- } \\
\text { Уітні }\end{array}$} & \multirow{2}{*}{$\begin{array}{c}\text { Коеф. зна- } \\
\text { чущості, } \\
\text { p } \leq 0,05\end{array}$} \\
\hline & & & к-сть & $\%$ & К-сть & $\%$ & & \\
\hline 1 & 2 & 3 & 4 & 5 & 6 & 7 & 8 & 9 \\
\hline \multirow{3}{*}{1.} & \multirow{3}{*}{$\begin{array}{c}\text { Рівень обізнано- } \\
\text { сті про передба- } \\
\text { чуваний перебіг } \\
\text { подій, ОП }\end{array}$} & високий & 5 & 11,11 & 4 & 8,89 & \multirow{3}{*}{721,00} & \multirow{3}{*}{0,018} \\
\hline & & середній & 32 & 71,11 & 34 & 75,55 & & \\
\hline & & низький & 8 & 17,78 & 7 & 15,56 & & \\
\hline \multirow{3}{*}{2.} & \multirow{3}{*}{$\begin{array}{c}\text { Рівень очікува- } \\
\text { ного ставлення } \\
\text { до учасників } \\
\text { міжособистісної } \\
\text { взаємодії, ОС о }\end{array}$} & високий & 13 & 28,89 & 13 & 28,89 & \multirow{3}{*}{923,50} & \multirow{3}{*}{0,117} \\
\hline & & середній & 28 & 62,22 & 31 & 68,89 & & \\
\hline & & низький & 4 & 8,89 & 1 & 2,22 & & \\
\hline \multirow{3}{*}{3.} & \multirow{3}{*}{$\begin{array}{l}\text { Рівень очікува- } \\
\text { них результатів } \\
\text { діяльності, ОР }\end{array}$} & високий & 11 & 24,44 & 12 & 26,67 & \multirow{3}{*}{675,50} & \multirow{3}{*}{0,006} \\
\hline & & середній & 31 & 68,89 & 31 & 68,89 & & \\
\hline & & низький & 3 & 6,67 & 2 & 4,44 & & \\
\hline \multirow{3}{*}{4.} & \multirow{3}{*}{$\begin{array}{c}\text { Рівень соціаль- } \\
\text { них очікувань, } \\
\mathrm{PCO}_{\mathrm{o}}\end{array}$} & високий & 17 & 37,78 & 18 & 40,00 & \multirow{3}{*}{688,50} & \multirow{3}{*}{0,009} \\
\hline & & середній & 24 & 53,33 & 25 & 55,56 & & \\
\hline & & ниЗьКий & 4 & 8,89 & 2 & 4,44 & & \\
\hline
\end{tabular}

* ЕГ - експериментальна група.

** КГ - контрольна група. 
Таблиия 5

Порівняння результатів показників властивостей соціальних очікувань експериментальної групи до та після формувального експерименту

\begin{tabular}{|c|c|c|c|c|c|c|c|c|c|}
\hline \multirow[t]{2}{*}{$\begin{array}{l}\text { № } \\
\text { 3/ } \\
\Pi\end{array}$} & \multirow{2}{*}{\multicolumn{2}{|c|}{$\begin{array}{c}\text { Показник властиво- } \\
\text { стей соціальних } \\
\text { очікувань, шкала }\end{array}$}} & \multirow[t]{2}{*}{ Рівень } & \multicolumn{2}{|c|}{$\begin{array}{c}\text { До експеримен- } \\
\text { ту (15 } \\
\text { співробітників) }\end{array}$} & \multicolumn{2}{|c|}{$\begin{array}{l}\text { Після експери- } \\
\text { менту (35 } \\
\text { співробітників) }\end{array}$} & \multirow{2}{*}{$\begin{array}{c}\text { Т-критерій } \\
\text { Ф.Вілкоксона } \\
\text { (сума рангів), } \\
\mathrm{T}_{\Pi},{ }^{*} \mathrm{~T}_{\mathrm{H}}{ }^{* *}\end{array}$} & \multirow{2}{*}{$\begin{array}{c}\text { Коеф. } \\
\text { значущос- } \\
\text { ті, } \\
\text { p } \leq 0,05\end{array}$} \\
\hline & & & & к-сть & $\%$ & К-сть & $\%$ & & \\
\hline 1 & & 2 & 3 & 4 & 5 & 6 & 7 & 8 & 9 \\
\hline \multirow{12}{*}{1.} & \multirow{12}{*}{ IE } & \multirow{3}{*}{$\begin{array}{c}\text { інтерналь- } \\
\text { ність }\end{array}$} & високий & 1 & 6,68 & 6 & 17,14 & \multirow{12}{*}{$\begin{array}{c}\text { позитивні } \\
16,00 \\
\text { негативні } \\
9,00\end{array}$} & \multirow{12}{*}{0,153} \\
\hline & & & середній & 2 & 13,33 & 6 & 17,14 & & \\
\hline & & & низький & 6 & 40,00 & 9 & 25,71 & & \\
\hline & & \multirow{3}{*}{$\begin{array}{c}\text { екстерналь- } \\
\text { ність }\end{array}$} & високий & 2 & 13,33 & 1 & 2,86 & & \\
\hline & & & середній & 2 & 13,33 & 5 & 14,29 & & \\
\hline & & & низький & 2 & 13,33 & 8 & 22,86 & & \\
\hline & & \multirow{3}{*}{$\begin{array}{c}\text { амбівалент- } \\
\text { ність }\end{array}$} & високий & 0 & 0,00 & 0 & 0,00 & & \\
\hline & & & середній & 0 & 0,00 & 0 & 0,00 & & \\
\hline & & & низький & 0 & 0,00 & 0 & 0,00 & & \\
\hline & & \multirow{3}{*}{ полярність } & високий & 0 & 0,00 & 1 & 2,86 & & \\
\hline & & & середній & 0 & 0,00 & 2 & 5,71 & & \\
\hline & & & низький & 0 & 0,00 & 1 & 2,86 & & \\
\hline \multirow{12}{*}{2.} & \multirow{12}{*}{$\begin{array}{c}\mathrm{A} \\
\Pi_{\mathrm{o}}\end{array}$} & \multirow{3}{*}{ активність } & високий & 1 & 6,67 & 6 & 17,14 & \multirow{12}{*}{$\begin{array}{l}\text { позитивні } \\
41,00 \\
\text { негативні } \\
10,00\end{array}$} & \multirow{12}{*}{0,043} \\
\hline & & & середній & 3 & 20,00 & 6 & 17,14 & & \\
\hline & & & низький & 5 & 33,34 & 9 & 25,72 & & \\
\hline & & \multirow{6}{*}{$\begin{array}{c}\text { амбівалент- } \\
\text { ність }\end{array}$} & високий & 2 & 13,33 & 1 & 2,86 & & \\
\hline & & & середній & 2 & 13,33 & 7 & 20,00 & & \\
\hline & & & НИЗький & 2 & 13,33 & 6 & 17,14 & & \\
\hline & & & високий & 0 & 0,00 & 0 & 0,00 & & \\
\hline & & & середній & 0 & 0,00 & 0 & 0,00 & & \\
\hline & & & низький & 0 & 0,00 & 0 & 0,00 & & \\
\hline & & \multirow{3}{*}{ полярність } & високий & 0 & 0,00 & 1 & 2,86 & & \\
\hline & & & середній & 0 & 0,00 & 1 & 2,86 & & \\
\hline & & & низький & 0 & 0,00 & 3 & 8,57 & & \\
\hline & & & високий & 3 & 20,00 & 7 & 20,00 & & \\
\hline & & відкритість & середній & 3 & 20,00 & 6 & 17,14 & позитивні & \\
\hline 3 & B3 & & низький & 4 & 26,67 & 9 & 25,72 & 95,00 & 0004 \\
\hline 3. & o & & високий & 2 & 13,33 & 1 & 2,86 & негативні & 0,004 \\
\hline & & закритість & середній & 2 & 13,33 & 6 & 17,14 & 0,00 & \\
\hline & & & низький & 1 & 6,67 & 6 & 17,14 & & \\
\hline & & & Високий & 0 & 0,00 & 0 & 0,00 & & \\
\hline & & амо1валент- & середній & 0 & 0,00 & 0 & 0,00 & & \\
\hline & & & низький & 2 & 13,33 & 0 & 0,00 & & \\
\hline & & & високий & 0 & 0,00 & 3 & 8,57 & & \\
\hline & & полярність & середній & 0 & 0,00 & 2 & 5,71 & & \\
\hline & & & низький & 1 & 6,67 & 4 & 11,43 & & \\
\hline & & & високий & 1 & 6,67 & 7 & 20,00 & & \\
\hline & & адекватність & середній & 2 & 13,33 & 5 & 14,29 & позитивні & \\
\hline 4 & $\mathrm{~A}$ & & низький & 3 & 20,00 & 11 & 31,42 & 28,00 & \\
\hline 4. & $\mathrm{H}_{\mathrm{o}}$ & & високий & 4 & 26,67 & 5 & 14,29 & негативні & 0,038 \\
\hline & & неадекват- & середній & 3 & 20,00 & 4 & 11,43 & 0,00 & \\
\hline & & & низький & 2 & 13,33 & 3 & 8,57 & & \\
\hline
\end{tabular}

\footnotetext{
$\mathrm{T}_{\mathrm{n}},{ }^{*}$ - сума позитивних рангів Т-критерія Ф. Вілкоксона. $\mathrm{T}_{\mathrm{H}}{ }^{*}$ - сума негативних рангів Т-критерія Ф. Вілкоксона.
} 
Порівняння результатів показників соціальних очікувань експериментальної та контрольної груп після формувального експерименту дало можливість констатувати, що формувальні впливи, які реалізовані на експериментальній групі мають значущі позитивні зміни показника обізнаності про передбачуваний перебіг подій $(U=721,00 ; p=0,018)$, значущі позитивні зміни очікуваних результатів діяльності (U=675,50; p=0,006) і значущі позитивні зміни показника рівня соціальних очікувань досліджуваних (U=688,50; $\mathrm{p}=0,009)$. Незначущими є позитивні зміни показника очікуваного ставлення до учасників міжособистісної взаємодії ( $U=923,50 ; p=0,117)$. Отримані показники значущих позитивних змін у незалежних вибірках підтверджують ефективність програми оптимізації розвитку та психокорекції соціальних очікувань особистості, і правомірність її застосування.

Перейдемо до аналізу результатів, що характеризують соціальні очікування як процес і результат конструювання, й відображення особистістю соціальної дійсності. Подамо зміни досліджуваних показників властивостей соціальних очікувань в експериментальній групі (див. табл. 5).

Порівняння результатів показників властивостей соціальних очікувань експериментальної групи до та після формувального експерименту показує зміни, що відбулися в експериментальній групі після формувальних впливів. Констатуємо значущі позитивні змі- ни у дихотомічних парах властивостей соціальних очікувань особистості: активність / пасивність $\left(\mathrm{T}_{\pi}=41,00 ; \mathrm{p}=0,043\right)$, відкритість / закритість $\left(\mathrm{T}_{п}=95,00 ; \mathrm{p}=0,004\right)$, адекватність / неадекватність $\left(\mathrm{T}_{\Pi}=28,00 ; \mathrm{p}=0,038\right)$. Незначущими $є$ позитивні зміни у дихотомічній парі властивостей - інтернальність / екстернальність $\left(\mathrm{T}_{\Pi}=16,00 ; \mathrm{p}=0,153\right)$. Показники $\mathrm{T}$ критерія Вілкоксона констатують схожу картину 3 студентською експериментальною групою. Очевидно, дихотомічна пара властивостей «інтернальність / екстернальність»володіє високою асиміляційною здатністю, i вимагає тривалих формувальних та психокорекційних впливів, які могли б забезпечити значущі зміни. Розглянемо результати змін досліджуваних показників властивостей соціальних очікувань у контрольній групі (див. табл. 6).

Порівняння результатів показників властивостей соціальних очікувань контрольної групи засвідчило також позитивні зміни. Значущими є зміни у дихотомічних парі властивостей соціальних очікувань особистості: відкритість / закритість $\left(\mathrm{T}_{п}=30,00 ; \mathrm{p}=0,043\right)$. Незначущими є позитивні зміни у дихотомічних парах властивостей: інтернальність / екстернальність $\left(\mathrm{T}_{п}=19,00 ; \mathrm{p}=0,179\right)$, активність / пасивність $\left(\mathrm{T}_{\text {п }}=11,50 ; \mathrm{p}=0,285\right)$, адекватність / неадекватність $\left(\mathrm{T}_{\Pi}=16,00 ; \mathrm{p}=0,086\right)$. Очевидно, організація соціокультурного середовища міжособистісної взаємодії торгового центру сприяла формуванню відкритості соціальних 


\section{Порівняння результатів показників властивостей соціальних очікувань контрольної групи до та після формувального експерименту}

\begin{tabular}{|c|c|c|c|c|c|c|c|c|c|}
\hline \multirow[t]{2}{*}{$\begin{array}{l}\text { № } \\
\text { 3/ } \\
\Pi\end{array}$} & \multirow{2}{*}{\multicolumn{2}{|c|}{$\begin{array}{c}\text { Показник властивостей } \\
\text { соціальних очікувань, } \\
\text { шкала }\end{array}$}} & \multirow[t]{2}{*}{ Рівень } & \multicolumn{2}{|c|}{$\begin{array}{c}\text { До експеримен- } \\
\text { ту ( } 24 \\
\text { співробітники) } \\
\end{array}$} & \multicolumn{2}{|c|}{$\begin{array}{c}\text { Після експери- } \\
\text { менту (31 } \\
\text { співробітник) } \\
\end{array}$} & \multirow{2}{*}{$\begin{array}{c}\text { Т-критерій } \\
\text { Ф.Вілкоксона } \\
\text { (сума рангів), } \\
\mathrm{T}_{\Pi},{ }^{*} \mathrm{~T}_{\mathrm{H}} * *\end{array}$} & \multirow{2}{*}{$\begin{array}{l}\text { Коеф. зна- } \\
\text { чущості, } \\
\text { p } \leq 0,05\end{array}$} \\
\hline & & & & К-сть & $\%$ & К-сть & $\%$ & & \\
\hline 1 & & 2 & 3 & 4 & 5 & 6 & 7 & 8 & 9 \\
\hline \multirow{12}{*}{1.} & \multirow{12}{*}{$\mathrm{IE}_{\mathrm{o}}$} & \multirow{3}{*}{ інтернальність } & високий & 4 & 16,67 & 4 & 12,90 & \multirow{12}{*}{$\begin{array}{l}\text { позитивні } \\
19,00 \\
\text { негативні } \\
4,00\end{array}$} & \multirow{12}{*}{0,179} \\
\hline & & & середній & 5 & 20,83 & 5 & 16,13 & & \\
\hline & & & низький & 8 & 33,33 & 11 & 35,49 & & \\
\hline & & \multirow{3}{*}{ екстернальність } & високий & 1 & 4,17 & 1 & 3,23 & & \\
\hline & & & середній & 2 & 8,33 & 4 & 12,90 & & \\
\hline & & & низький & 4 & 16,67 & 6 & 19,35 & & \\
\hline & & \multirow{3}{*}{ амбівалентність } & високий & 0 & 0.00 & 0 & 0,00 & & \\
\hline & & & середній & 2 & 8,33 & 2 & 6,45 & & \\
\hline & & & низький & 1 & 4,17 & 1 & 3,23 & & \\
\hline & & \multirow{3}{*}{ полярність } & високий & 0 & 0,00 & 0 & 0,00 & & \\
\hline & & & середній & 0 & 0,00 & 0 & 0,00 & & \\
\hline & & & низький & 1 & 4,17 & 1 & 3,23 & & \\
\hline \multirow{12}{*}{2.} & \multirow{12}{*}{$\begin{array}{c}\mathrm{A} \\
\Pi_{\mathrm{o}}\end{array}$} & \multirow{3}{*}{ активність } & високий & 4 & 16,67 & 4 & 12,90 & \multirow{12}{*}{$\begin{array}{l}\text { позитивні } \\
11,50 \\
\text { негативні } \\
6,50\end{array}$} & \multirow{12}{*}{0,285} \\
\hline & & & середній & 6 & 25,00 & 6 & 19,35 & & \\
\hline & & & низький & 7 & 29,16 & 9 & 29,04 & & \\
\hline & & \multirow{6}{*}{ амбівалентність } & високий & 1 & 4,17 & 3 & 9,68 & & \\
\hline & & & середній & 2 & 8,33 & 5 & 16,13 & & \\
\hline & & & низький & 4 & 16,67 & 4 & 12,90 & & \\
\hline & & & високий & 0 & 0,00 & 0 & 0,00 & & \\
\hline & & & середній & 3 & 12,50 & 3 & 9,68 & & \\
\hline & & & НИзьКий & 1 & 4,17 & 1 & 3,23 & & \\
\hline & & \multirow{3}{*}{ полярність } & високий & 0 & 0,00 & 0 & 0,00 & & \\
\hline & & & середній & 0 & 0,00 & 1 & 3,23 & & \\
\hline & & & НизьКий & 1 & 4,17 & 0 & 0,00 & & \\
\hline & & & Високий & 6 & 25,00 & 6 & 19,35 & & \\
\hline & & відкритість & середній & 6 & 25,00 & 6 & 19,35 & & \\
\hline & & & низький & 6 & 25,00 & 9 & 29,04 & & \\
\hline & & & високий & 0 & 0,00 & 1 & 3,23 & & \\
\hline & & закритість & середній & 2 & 8,33 & 4 & 12,90 & позитивні & \\
\hline & B3 & & низький & 4 & 16,67 & 5 & 16,13 & 30,00 & \\
\hline 3. & o & & високий & 0 & 0,00 & 0 & 0,00 & негативні & 0,043 \\
\hline & & амбівалентність & середній & 0 & 0,00 & 0 & 0,00 & 4,00 & \\
\hline & & & низький & 3 & 12,50 & 3 & 9,68 & & \\
\hline & & & високий & 1 & 4,17 & 1 & 3,23 & & \\
\hline & & полярність & середній & 1 & 4,17 & 1 & 3,23 & & \\
\hline & & & низький & 1 & 4,17 & 0 & 0,00 & & \\
\hline & & & високий & 4 & 16,67 & 5 & 16,13 & & \\
\hline & & адекватність & середній & 7 & 29,16 & 8 & 25,81 & позитивні & \\
\hline & A & & Низький & 4 & 16,67 & 4 & 12,90 & 16,00 & \\
\hline 4. & $\mathrm{H}_{\mathrm{o}}$ & & високий & 1 & 4,16 & 4 & 12,90 & негативні & 0,080 \\
\hline & & неадекватність & середній & 4 & 16,67 & 5 & 16,13 & & \\
\hline & & & низький & 4 & 16,67 & 5 & 16,13 & & \\
\hline
\end{tabular}

$\mathrm{T}_{\mathrm{n}}$, - сума позитивних рангів Т-критерія Ф. Вілкоксона.

$\mathrm{T}_{\mathrm{H}}^{* *}$ - сума негативних рангів Т-критерія Ф. Вілкоксона. 
Порівняння результатів показників властивостей соціальних очікувань експериментальної та контрольної груп після формувального експерименту

\begin{tabular}{|c|c|c|c|c|c|c|c|c|c|}
\hline \multirow{2}{*}{$\begin{array}{l}\text { № } \\
\text { 3/ } \\
\Pi 1\end{array}$} & \multirow{2}{*}{\multicolumn{2}{|c|}{$\begin{array}{c}\text { Показник властивостей } \\
\text { соціальних очікувань, } \\
\text { шкала }\end{array}$}} & \multirow[t]{2}{*}{ Рівень } & \multicolumn{2}{|c|}{$\begin{array}{c}\text { ЕГ* }(35 \\
\text { співробітників) }\end{array}$} & \multicolumn{2}{|c|}{$\begin{array}{c}\text { КГ** (31 } \\
\text { співробітник) }\end{array}$} & \multirow{2}{*}{$\begin{array}{l}\text { U-критерій } \\
\text { Манна-Уітні }\end{array}$} & \multirow{2}{*}{$\begin{array}{l}\text { Коеф. зна- } \\
\text { чущості, } \\
\text { p } \leq 0,05\end{array}$} \\
\hline & & & & К-сть & $\%$ & К-сть & $\%$ & & \\
\hline 1 & & 2 & 3 & 4 & 5 & 6 & 7 & 8 & 9 \\
\hline \multirow{12}{*}{1.} & \multirow{12}{*}{$\mathrm{IE}_{\mathrm{o}}$} & \multirow{3}{*}{ інтернальність } & високий & 6 & 17,14 & 4 & 12,90 & \multirow{12}{*}{795,50} & \multirow{12}{*}{0,065} \\
\hline & & & середній & 6 & 17,14 & 5 & 16,13 & & \\
\hline & & & низький & 9 & 25,71 & 11 & 35,49 & & \\
\hline & & \multirow{3}{*}{ екстернальність } & високий & 1 & 2,86 & 1 & 3,23 & & \\
\hline & & & середній & 5 & 14,29 & 4 & 12,90 & & \\
\hline & & & низький & 8 & 22,86 & 6 & 19,35 & & \\
\hline & & \multirow{3}{*}{ амбівалентність } & високий & 0 & 0,00 & 0 & 0,00 & & \\
\hline & & & середній & 0 & 0,00 & 2 & 6,45 & & \\
\hline & & & Низький & 0 & 0,00 & 1 & 3,23 & & \\
\hline & & \multirow{3}{*}{ полярність } & високий & 1 & 2,86 & 0 & 0,00 & & \\
\hline & & & середній & 2 & 5,71 & 0 & 0,00 & & \\
\hline & & & низький & 1 & 2,86 & 1 & 3,23 & & \\
\hline \multirow{12}{*}{2.} & \multirow{12}{*}{$\begin{array}{l}\mathrm{A} \\
\prod_{\mathrm{o}}\end{array}$} & \multirow{3}{*}{ активність } & високий & 6 & 17,14 & 4 & 12,90 & \multirow{12}{*}{745,50} & \multirow{12}{*}{0,036} \\
\hline & & & середній & 6 & 17,14 & 6 & 19,35 & & \\
\hline & & & низький & 9 & 25,72 & 9 & 29,04 & & \\
\hline & & \multirow{6}{*}{ амбівалентність } & високий & 1 & 2,86 & 3 & 9,68 & & \\
\hline & & & середній & 7 & 20,00 & 5 & 16,13 & & \\
\hline & & & НиЗький & 6 & 17,14 & 4 & 12,90 & & \\
\hline & & & високий & 0 & 0,00 & 0 & 0,00 & & \\
\hline & & & середній & 0 & 0,00 & 3 & 9,68 & & \\
\hline & & & низький & 0 & 0,00 & 1 & 3,23 & & \\
\hline & & \multirow{3}{*}{ полярність } & високий & 1 & 2,86 & 0 & 0,00 & & \\
\hline & & & середній & 1 & 2,86 & 1 & 3,23 & & \\
\hline & & & Низький & 3 & 8,57 & 0 & 0,00 & & \\
\hline & & & високий & 7 & 20,00 & 6 & 19,35 & & \\
\hline & & відкритість & середній & 6 & 17,14 & 6 & 19,35 & & \\
\hline & & & низький & 9 & 25,72 & 9 & 29,04 & & \\
\hline & & & високий & 1 & 2,86 & 1 & 3,23 & & \\
\hline & & закритість & середній & 6 & 17,14 & 4 & 12,90 & & \\
\hline 3 & B3 & & низький & 6 & 17,14 & 5 & 16,13 & 80100 & 0102 \\
\hline$J$. & o & & високий & 0 & 0,00 & 0 & 0,00 & 801,00 & \\
\hline & & амбівалентність & середній & 0 & 0,00 & 0 & 0,00 & & \\
\hline & & & низький & 0 & 0,00 & 3 & 9,68 & & \\
\hline & & & високий & 3 & 8,57 & 1 & 3,23 & & \\
\hline & & полярність & середній & 2 & 5,71 & 1 & 3,23 & & \\
\hline & & & низький & 4 & 11,43 & 0 & 0,00 & & \\
\hline & & & високий & 7 & 20,00 & 5 & 16,13 & & \\
\hline & & адекватність & середній & 5 & 14,29 & 8 & 25,81 & & \\
\hline 4 & $\mathrm{~A}$ & & низький & 11 & 31,42 & 4 & 12,90 & 73000 & 0032 \\
\hline 4. & $\mathrm{H}_{\mathrm{o}}$ & & високий & 5 & 14,29 & 4 & 12,90 & 150,00 & 0,032 \\
\hline & & неадекватність & середній & 4 & 11,43 & 5 & 16,13 & & \\
\hline & & & Низький & 3 & 8,57 & 5 & 16,13 & & \\
\hline
\end{tabular}

* ЕГ-експериментальна група.

** КГ - контрольна група. 
очікувань учасників. Значущі зміни у всіх інших властивостях соціальних очікувань вимагають цілеспрямованих формувальних впливів.

Розглянемо результати показників властивостей соціальних очікувань експериментальної та контрольної груп після формувального експерименту (див. табл. 7).

Порівняння результатів показників властивостей соціальних очікувань експериментальної та контрольної груп після формувального експерименту показує, що значущі зміни зафіксовано у дихотомічних парах властивостей соціальних очікувань особистості: активність / пасивність $\left(\mathrm{T}_{\Pi}=745,50 ; \mathrm{p}=0,036\right)$ і адекватність / неадекватність $\left(\mathrm{T}_{\mathrm{II}}=730,00 ; \mathrm{p}=0,032\right)$. У всіх інших парах зміни незначні: інтернальність / екстернальність $\left(\mathrm{T}_{\Pi}=795,50 ; \mathrm{p}=0,065\right)$, відкритість / закритість $\left(\mathrm{T}_{\Pi}=801,00 ; \mathrm{p}=0,102\right)$. Незначущі позитивні зміни у дихотомічній парі - відкритість / закритість пояснюємо тим, що навіть без формувальних впливів, соціокультурне середовище міжособистісної взаємодіï торгового центру забезпечує сприятливі умови для формування високих показників відкритості соціальних очікувань учасників взаємодії.

Висновки. Формувальні впливи програми тренінгів та післятренінгового супроводження «Очікуваний результат» сприяли швидким якісним змінам соціальної дійсності у торговому центрі «33 ${ }^{2}$ етра» (м. БілгородДністровський). Програма оптимізації розвит- ку та психокорекції соціальних очікувань забезпечила формування необхідних навичок ефективної комунікації, організації роботи 3 продажу товарів, формування уявлень про ефективну реалізацію бізнес-процесу та спробу його реалізувати, а застосування комбінованої моделі навчально-професійної підготовки дозволило закріпити на практиці вищеперелічені вміння та навички. Найближчі перспективи подальших наукових розвідок вбачаємо в обгрунтуванні результатів реалізації програми оптимізації розвитку та психокорекції соціальних очікувань особистості.

\section{Перелік використаних джерел:}

1. Ломов Б. Ф. Методологические и теоретические проблемы психологии / Б.Ф. Ломов. - М. : Наука, 1984. $444 \mathrm{c}$.

2._атенко В. О. Про теоретико-методологічні засади психологічного дослідження суспільних явищ / В.О. Татенко // Наукові студії із соціальної та політ. психол. : зб. статей. - 2000. - Вип. 2 (5). - С. 19-26.

\section{References (Transliteration):}

1. Lomov B.F. Metodologicheskie i teoreticheskie problemy psihologii / B. F. Lomov. - M. : Nauka, 1984. - 444 s.

2. Tatenko V. O. Pro teoretiko-metodologichni zasadi psihologichnogo doslidzhennja suspil'nih javishh / V. O. Tatenko // Naukovi studiï iz social'noï ta polit. psihol. : zb. statej. - 2000. - Vip. 2 (5). - S. 19-26.

(C) Попович I. C. 


\section{Popovych Igor Stepanovych}

Associate professor, candidate of psychological sciences, assistant professor of pedagogy, psychology and educational management of Kherson State University, Kherson (Ukraine)

\section{EVALUATING THE EFFECTIVENESS OF OPTIMIZING PROGRAM OF DEVELOPMENT AND PSYCHOCORRECTION OF SOCIAL EXPECTATIONS OF PERSONALITY}

\section{ABSTRACT}

In the article, contensive and process features of optimizing program of correction and social expectations of personality are proved. It is defined principles and it is described organization and conditions of the forming phase of the study. It is posted training sessions and aftertraining support «Expective output». It is disclosed the essence of directions of forming and correctional phase of research program: forming and developing, prevention and correction. We can also outline appropriateness and content features of aftertraining support.

A control stage of the pilot study has been realized. The main results of the implementation of program study of social expectations of personality are considered. It is evaluated the efficiency of the optimizing program of development and psychological correction of social expectations of personality. It is grounded a substantiation of received experimental research results.

It is concluded that the implementation of the optimizing program of the development and psychological correction of social expectations provided the formation of ideas about effective realization of business processes, necessary skills of effective communication, management of the sale of goods. Application of combined model of educational training has allowed to consolidate above listed skills.

Key words: social expectations, optimization of social expectations, social expectations psychocorrection program of research.

\section{Попович Игорь Степанович}

Кандидат психологических наук, доиент, дочент кафедры педагогики, психологии и образовательного менеджмента Херсонского государственного университета, Херсон (Украина)

\section{ОЦЕНКА ЭФФЕКТИВНОСТИ ВНЕДРЕНИЯ ПРОГРАММЫ ОПТИМИЗАЦИИ РАЗВИТИЯ И ПСИХОКОРРЕКЦИИ СОЦИАЛЬНЫХ ОЖИДАНИЙ ЛИЧНОСТИ}

Аннотация. В статье обоснованы содержательно-процессуальные особенности программы оптимизации развития и психокоррекции социальных ожиданий личности. Определены принципы, описано организацию и условия проведения формирующего этапа исследования. Подано программу тренинговых занятий и посттренингового сопровождения «Ожидаемый результат». Раскрыта сущность направлений формирующекоррекционного этапа программы исследования: формирующе-развивающего, профилактики и психокоррекции. Определены целесообразность и содержательные особенности послетренингового сопровождения.

Проведен контрольный этап экспери- 
ментального исследования. Рассмотрены основные результаты внедрения программы исследования социальных ожиданий личности. Оценена эффективность внедрения программы оптимизации развития и психокоррекции социальных ожиданий личности. Осуществлено обоснование полученных экспериментальных результатов исследования.

Сделан вывод, что реализация программы оптимизации развития и психокоррекции социальных ожиданий обеспечила формирование представлений об эффективной реализации бизнес-процессов, необходимых навыков эффективной коммуникации, организации работы по продаже товаров. Применение комбинированной модели учебнопрофессиональной подготовки позволило закрепить на практике вышеперечисленные умения и навыки.

Ключевые слова: социальные ожидания, оптимизация развития социальных ожиданий, психокоррекция социальных ожиданий, программа исследования. 